\title{
Research on Logistics Development Strategy of an Light Industry and Salt Industry Group under the Background of System Reform of Salt Industry
}

\author{
Shijun Yuan \\ Hunan Vocational College of Modern Logistics \\ Changsha, China 410131
}

\author{
Jianhua Chen* \\ Hunan Vocational College of Modern Logistics \\ Changsha, China 410131 \\ *Corresponding Author
}

\begin{abstract}
The seventh system reform of salt industry of the country casts a large impact on salt industry enterprises in China. How to integrate social resources and give full play to their original advantages in a new market-oriented competitive environment is an important field in which many salt companies are actively exploring. Through the deep analysis of the foundations, problems, opportunities, and challenges that logistics industry development of an salt industry enterprise face, this paper studies the guiding ideology, strategic positioning, development goals, spatial strategies, and overall layout of the logistics development strategy of the enterprise and also provides reference for the enterprise development.
\end{abstract}

Keywords—salt industry; logistics; strategy

\section{INTRODUCTION}

With the rapid development of China's economy, the salt chemical industry has made rapid progress, meanwhile, China has become an important salt chemical production country in the world. On May 5, 2016, the State Council issued a plan on system reform of salt industry, named seventh salt reform by the salt industry, which inspires its market vitality and development momentum. Under this background, how to integrate existing logistics resources with new facilities; construct a modern logistics network system; and guide the development of salt industry logistics and food logistics towards modernization, scale, information, and standardization is an issue that salt industry enterprises need to study urgently.

\section{BASIC CONDITIONS OF LOGISTICS INDUSTRY} DEVELOPMENT OF AN LIGHT INDUSTRY AND SALT INDUSTRY GROUP

A. The Comprehensive Strength of an Light Industry and Salt Industry Group Ranks in the Forefront of the Industry in the Country

The light industry and salt industry group is a state-owned large enterprise affiliated by the province integrating "engineering, trade, science and education". This company mainly takes the production and wholesale of salt products, plastic products industry and capital operation as the main businesses, engages in real estate, construction and installation, circulation trade, scientific and technological development, survey and design, and vocational education, performs the province's salt monopoly function according to law, and owns 16 companies, including wholly-owned, controlled, shareholding companies and research and design institutes. The salt industry joint-stock company, holding subsidiary of the group, is the first modern joint-equity enterprise of trans-provincial joint and production and marketing integration in the salt industry in the country. The two salt and chemical industry companies under its jurisdiction are the key enterprises in the well and rock salt industry and the salt designated production enterprises of the country. They have passed ISO9001:2000 quality certification and have an annual production capacity of 3 million tons. The group has more than ten thousand employees and owns total assets of nearly 10 billion yuan, and its comprehensive strength ranks in the forefront of the same industry.

\section{B. The Performance of Main Business Has Steadily Increased in Recent Years}

In recent years, the company has strengthened the propaganda and marketing training for the non-salt products, and the non-salt commodity marketing in the whole province has formed a management pattern focusing on the exclusive distribution products of centralized purchasing, supplemented by local self-selected brands. It has selected 3 categories and 10 brands and strengthened cooperation with many first-tier brands; the major commodities such as pulp, non-ferrous metals, and chemical raw materials, have entered a good developmental trajectory and gained expected returns. The business development performance of the company has been steadily increasing. The annual sales revenue is about 3 billion yuan and the profit is about 300 million yuan.

\section{The Light Industry and Salt Industry Group Basically Has} Objective Conditions to Develop Modern Logistics

Since the reform and opening up, the storage, transportation, handling, and packaging conditions of the Group's salt and non-salt foods have been continuously improved and the level of technology has been continuously promoted. The annual circulation of salt and non-salt foods has 
increased year by year and the objective conditions to develop f modern logistics have basically been met.

The salt industry joint-stock company under the jurisdiction of the Group has 14 municipal controlled companies with a total storage area of approximately 200,000 square meters, including 70,000 square meters of its own warehouse, and the storage facilities are relatively complete. A salt mine of the Group has a railway freight trestle with an annual freight mileage of 1 million tons, and the Group's B salt mine has 1 inland river cargo berth with an annual cargo handling capacity of 1 million tons. By the way of railways, highways, and water transportation methods, the freight mileage of salt nitrate of the Group has exceeded 3 million tons.

The warehouses owned by the Group basically have the functions of receiving, transferring, distributing and delivering salt and non-salt foods by railways, highways and waterways. Parts of the warehouses of the four branch companies are newly built in recent years, and the new warehouses are equipped with advanced storage equipment and detection management system such as mechanical ventilation, inspection and motor truck scale. Basically, the goods entering and leaving the warehouse have achieved mechanical operation, which has effectively promoted the modernization of the Group's salt and non-salt food logistics systems.

As the provincial new high-tech enterprise, the Group has many invention patents, including 2 China famous brands, 5 Chinese famous brand products, 8 national free-inspection quality products, and 15 provincial brand names.

\section{PROBLEMS OF LOGISTICS DEVELOPMENT}

\section{A. The Development Space of Some Logistics Nodes Is Limited}

Most of the logistics infrastructures of the company are concentrated in the core area of the old city. Most of the warehouses have been built for a long time, and some of them are built in brick and wood structures; and due to the long-term storage of corrosive salt products, the buildings are seriously damaged. Moreover, a large number of residents live around them, and there are hidden traffic hazards in the mixed traffic flow of passengers and logistics, and access of large trucks is extremely inconvenient.

Commercial logistics mostly belong to commercial and residential mixing and front-house and back-home models, and potential safety hazard actually exists. The emerging offline experiences, online trade and offline delivery and other forward and reverse $\mathrm{O} 2 \mathrm{O}$ modes have not yet emerged.

With the constantly in-depth urbanization process, the warehouses of some branch companies are already in the scope of relocation of local government departments and are urgently needed to be relocated.

Most of the existing station yards cannot meet the basic requirements of freight market, including the entry of freight transportation enterprises, parking of vehicles, loading and unloading, and storage of goods. In the future, the scale of land expansion will be limited and there will be no expand space to support industry development.

\section{B. The Existing Warehouse Facilities Need to Be Upgraded and Transformed}

Most of the existing warehouse facilities are obsolete, and the automation level of loading and unloading is low, which cannot meet the needs of modern logistics loading and unloading. The loading and unloading of most of the salt and non-salt foods are still loaded and unloaded by the traditional method of manpower, which results in low efficiency, high labor intensity, and serious personnel loss, is difficult to adapt to the development needs of the modern logistics industry, therefore, transformation and upgrading is extremely urgent.

\section{The Service Ability of Logistics Enterprise Is Limited}

From the perspective of the internal structure of the logistics industry, the service level of logistics companies is limited, and the service content is still dominated by traditional transportation and wholesale and retail. Modern logistics, computer services, information consulting, and logistics finance services are small in scale and stay in initial stage. Highway ports, bonded logistics, e-commerce logistics, multimodal transport, supply chain logistics and other highend logistics commercial activities need to be developed.

\section{The Cost of Existing Circulation Pattern Is High}

The circulation of existing light industry and salt industry group need to pass seven links: manufacturing enterprise - salt industry company at provincial level—salt industry company at city level-salt industry company at county levelaccommodation sale enterprise-retail outlets-final user. Therefore, there are many links in the supply chain, the supply is slow, and the cost of transportation and warehousing is high.

\section{THE OPPORTUNITIES AND CHALLENGES FOR THE DEVELOPMENT OF LIGHT INDUSTRY AND SALT INDUSTRY LOGISTICS COEXIST}

\section{A. Opportunities for Development}

The key point of the national economy development is shifted from highlighting the economic growth rate to improving the quality of economic development. We will maintain a stable and healthy economy by strengthening and improving macro-control, and enhance the coordination and competitiveness of economic development through deepening reforms and opening up and strategic adjustment of economic structures, so as to realize the transformation of the mode of economic growth. Meanwhile, through proactive fiscal policy and steady monetary policy, we will effectively curb inflation to achieve steady growth of the national economy. It is expected that the macro economy situation will develop steadily and rapidly during the planning period, and the financing environment of the enterprise will be tighter, and the enterprise's business environment will face new challenges and opportunities.

The reform of the salt industry system must be enforced. The reform plan has been approved by the director office 
meeting of the National Development and Reform Commission, and has solicited advice from all ministries and commissions. The reform plan includes six sections and 20 parts, with a core of abolishing salt monopoly. Its specific content is to abolish the relevant regulations on salt monopoly from 2016, allow the salt circulation enterprises to conduct trans-regional operation, and liberalize the salt wholesale and circulation management. Since 2017, the salt industry has been fully implemented based on the new plan. Once the salt monopoly system is liberalized, it will be a "double-edged sword" for salt production enterprises, which will intensify market competition and increase operating risks. It will be a completely competitive market for the salt marketing enterprises. The market share, sales revenue and profitability will drop sharply, what's more, enterprises will suffer largescale losses and face a survival crisis.

Opportunities for development: the policy supports salinealkali integration. The demand of industrial salt including sodium carbonate and caustic soda for well and rock salt will maintain a moderate growth. The financing channels of capital market increase, and the salt industry system reform provides a completely competitive market, which will promote the merger and reorganization of enterprises. From another point of view, at present, the proportion of the logistics cost of the developed countries in Europe and America to GDP is less than 10\%. The logistics expenditure of the whole society accounts for $18 \%$ of GDP in the current production of industrial enterprises in China, and there is huge room to be improved.

\section{B. Challenges Facing}

Currently, major challenges for the development of enterprise are: policy risks brought by system reform of salt industry, the decline of major products' price due to financial crisis, the increase of cyclical fluctuation range in salt market, and the higher demand for energy saving and environmental protection.

\section{DEVELOPMENT STRATEGY AND GOALS}

\section{A. Guiding Ideology}

Taking the spirit of the 19th National Congress of the Communist Party of China as the lead, we will adhere to the direction of marketization, insist on innovative development and transformation development, and closely focus on the strategic objectives defined in the "2015-2020 Reform and Development Program" of the enterprise group. Taking struggling to rise up and spanning development as the theme, we will integrate the internal and external logistics resources of the group, perfect the logistics infrastructure, build a full supply chain integration logistics service system of "salt industry" and "food industry", and plan to create a long-term food cold chain logistics at the same time, so as to promote the rapid development of the "salt plate" and "food plate" industry of the group company.

\section{B. Strategic Positioning}

Under the orientation of market demand, we will closely keep pace with the development trend of logistics at home and abroad, and make full use of industry base, information technology, logistics network, financial platform and resources advantages. Relying on international domestic logistics channel, we will expand open cooperation, upgrade and upgrade commercial and trading formats, improve comprehensive service capabilities, enhance regional radiation and driving capacity, and create an integrated service platform for the "salt products and food industry" supply chain logistics (including cold chain).

\section{Development Goals}

We will accelerate the transformation and upgrading of existing facilities, scientifically plan and rationally arrange the new logistics facilities, form a logistics space layout with reasonable division of labor, distinctive characteristics, and resource elements gathering, and seamlessly dock the Silk Road Economic Belt and Yangtze River Economic Zone. Supported by logistics information platform and e-commerce platform, combining with the tangible market and the virtual market, we will strive to improve the standardization, informatization, intelligence and intensive level of the logistics industry of Light Industry \& Salt Industry Group, improve the overall operation efficiency and effectiveness of economy, so as to achieve the new power and new economic growth point of economic development of the Group and area, and further consolidate and enhance the leading position of the Group in salt products and food trade logistics industry in Southern China.

By 2020, we will construct a supply chain integration logistics service system of "salt products and food" radiating the whole province and the surrounding provinces and cities, realize an annual logistics turnover of approximately 10 million tons, and achieve a reduction of $1 \%$ of the proportion of Group's logistics fees to sales revenue.

\section{SPATIAL StRATEGY AND GENERAL LAyOUT}

\section{A. Spatial Strategy}

1) Rely on regional transportation advantages, and build a modern commercial logistics park for salt products and food: According to the strategy guidance that "connects regional market and makes well regional logistics center", relying on the traffic regional advantages in the region, plan and establish a modern salt products and food commercial logistics park at the most convenient locations for transportation, and set up regional salt products and food supply chain trade logistics service platforms in accordance with the features of supply-demand structure and circulation direction of logistics of the market.

2) Integrate existing logistics resources, improve quality and build new specialized logistics centers: After several years of development, all the controlled companies of light industry and salt industry group at city and province level have equipped with certain logistics infrastructure and logistics service capacity. To cope with the booming logistics quantity of the Group in the future, it should establish a newly regional and specialized logistics centers at the relatively weak area of the logistics service to meet the requirements of 
overall planning on the basis of integrating the resources and improving quality and transformation according to the operation mode of logistics integrated of the Group.

3) Relieve the center and increase periphery, balance the distribution network setting up of "salt products and food": According to the construction planning of logistics network that covers all the area of province constructed by the Group, reasonably deploy the spatial arrangement of logistics network of "salt products and food" within the scope of each logistics center radiates, construct balanced, ordered, efficient and reasonable "salt products and food" logistics distribution system.

\section{B. General Layout}

Guided by the strategy of logistics space, we will build a logistics system with "one park, three bases, ten centers and multiple terminals" for Light Industry \& Salt Industry Group.

"One park": one modern food commercial logistics park.

"Three bases": improve the quality of the enterprise's three original salt storage infrastructure, and transform them into three major storage bases.

"Ten centers": according to the current distribution situation of sales companies and customers, build six logistics centers in the province, and four logistics centers outside the province.

"Multiple terminals (delivery terminal)": to meet the needs of franchise sites, retail stores, supermarket chains, and direct users, we plan to build a number of distribution terminals in each county. We can improve and transform the logistics infrastructure in the existing circulation channels of the company, and build more than 100 distribution terminals (stations) at the county level in the province.

At the same time, match and build the three supporting platforms including "food inspection and safety traceability, ecommerce and logistics information" with the goal of "safety", smooth "logistics, business flow, information flow and capital flow".

\section{CONCLUSION}

In order to ensure the realization of enterprise's logistics development strategy, we also need to actively promote some aspects, for example, reconstruct logistics organization structure, strengthen organizational guarantee, integrate supply chain, improve logistics service capacity to form brand advantages, innovate marketing mode, construct modern marketing channel system, convert logistics concept and strengthen logistics talent construction.

\section{REFERENCES}

[1] Liu Guang, Research on the optimization of distribution logistics system of Hunan Light Salt Group[D].Hunan University [D].2011. 刘光, 湖南轻盐集团配送物流系统优化研究 [D]. 湖南大学硕士论文 [D].2011.
[2] Xu Wenjing. Logistics Strategic Planning and Model [D]. China Machine Press. 2002. 徐文静.物流战略规划与模式[D].机械工业出版 社.2002.

[3] Ma Chenglin, Mao Haijun, Li Xuhong. The layout of interior functional areas in logistics parks [J]. Journal of Traffic and Transportation Engineering. 2008. 马成林, 毛海军, 李旭宏. 物流园区内部功能区 布局方法[J]. 交通运输工程学报.2008.

[4] Fu Zhongping. Layout Planning and Function Optimization of Zhejiang Jiabao Logistics Park [J]. Railway Freight Transport.2016. 傅钟萍. 浙 江嘉宝物流园区布局规划方案及其功能优化[J]. 铁道货运.2016.

[5] Shi Jun. Study on the functional orientation and spatial layout planning of Zhaojiao Group Logistics Park [J]. Kunming University of Science and Technology. 2015. 石筠. 昭交集团物流园区功能定位及空间布局 规划研究[J]. 昆明理工大学.2015. 